\title{
Metal Based Nanoparticles, a Novel Approach to Control Biofilm: Review
}

\author{
Himasri Das* \\ Department of Veterinary Microbiology, College of Veterinary Science Khanapara, \\ Guwahati-781022, Assam Agricultural University, India \\ *Corresponding author
}

\section{A B S T R A C T}

\begin{tabular}{|l|}
\hline Ke y w o r d s \\
$\begin{array}{l}\text { Bacterial Biofilm, } \\
\text { Metal based } \\
\text { nanoparticles }\end{array}$ \\
\hline Article Info \\
\hline $\begin{array}{l}\text { Accepted: } \\
\text { 24 August } 2020 \\
\text { Available Online: } \\
\text { 10 September } 2020\end{array}$ \\
\hline
\end{tabular}

Biofilm is a large collection of colonies containing sessile bacteria which are adhered onto the surface and embedded in the self produced biopolymers such as Extracellular Polymeric Substances (EPS). The surface may be present either in soil or aquatic system as well as in any medical devices or living tissue. These polymeric substances form a cohesive network that interconnects and immobilizes the biofilm cells helping them in mechanical stability. Production of biofilm ultimately helps the bacteria to survive the hostile environment such as different phagocytic cells encountered in living tissue and different harsh conditions like heat, cold, shear forces, desiccation that the inert surface is exposed to. Biofilms are often difficult to treat because of their inherent resistance to both host defens system and antimicrobial agents that ultimately results in persistent infection. Therefore, now a days different nano particles are targeted against biofilms by analyzing and manipulating various atoms using nano technology. This review aims to summerize the current novel solutions to fight against the multi-drug related problems using metal based nanoparticles to target the biofilms.

\section{Introduction}

Biofilm can be defined as a microbial community formed by number of sessile cells that are reversely attached first to a substratum and then on the interface to each other, embedded in extracellular polymeric substance (EPS) produced by the microorganism themselves (Davies, 1998; Decho, 2010). They exhibit different phenotypes from the wild ones with respect to their growth as well as few gene transcriptions (Donlan and Costerton, 2002). The planktonic bacteria, free floating microorganisms are the prerequisite for biofilm production (Chaudhari et al., 2012). They are formed on solid or liquid surface as well as on the surface of the living tissue that can serve as their nutrient source (Huang et $a l ., 2009)$. The process of development of a biofilm is often influenced by the physico chemical properties of the underlying surface where they are attached (Hannig and Hannig, 2009). It may contain the bacteria of either of same or of different species that attach to inert or living surface (O'Toole et al., 2000). Biofilm production is a common survival mechanism of pathogenic bacteria that 
ultimately leads to antibiotic resistance and reduce host immune clearance (Singh and Barbul 2008; O'Toole et al., 2000). It has been reported that most of the persistent infectious diseases occur due to presence of biofilm (Hall-Stoodley 2004; Marsh et al., 2000) and cause high cost involvement annually for treatment i.e. it almost exceeds 81 billion in United States (Flemmig et al., 2000). For the irreversible attachment on the surface there are certain receptors either protruding through or attached to the cell membrane that can bind to the ligands on the surface with strong but non covalent bonds (Busscher et al., 1987). Usually in the extracellular polymeric substance matrix many substances are present like extracellular proteins, phospholipid, teichoic acids, nucleic acids and exo polysaccharides that are produced by the microorganisms within the biofilm. However, there is also evidence of presence of silts, mineral salts, blood components and milk residues depending on the sites and the environmental condition under which the biofilms are produced (Costerton et al., 1995). The occurrence of biofilm is mostly studied in dental plaque or dental carries like infections, medical device related infections, systic fibrosis and different water bodies like marine surfaces, natural water as well as the waste water processing systems and even on the soil particles (Costerton, 1999). The bacteria can produce various signalling molecules to communicate with other bacteria of either same or different species or sometimes even with the host in response to change in the environment through altering the gene expression which is often density dependent or growth stage dependent (Holban and Lazar, 2011). The switching of the microorganisms from growth phase to transient dormant phase makes them resistant to different antimicrobial agents as well as drugs (Keren et al., 2004). In this review it is discussed about controlling biofilm formation by means of the novel approach nanotechnology which improves the poor penetration of antibiotics or any drug in the biofilm.

The trends in nanotechnology can be used as an alternative to traditional antibiotics for effective extermination of biofilms. The word "Nano" is a Greek word which means dwarf so the term nanotechnology is basically manipulation of atoms by atoms (Schleyer, 2000; Whitesides, 2001).

Different inorganic nanoparticles are gaining attention as new approach to combat the challenge against antibiotic resistance. The metal ions like gold, copper, silver, zinc, iron and titanium are adopted for various research works to see their antimicrobial activities (Ramasamy and Lee, 2016). Out of them Silver metal has shown to be superior in terms of antibacterial activity that acts on the sulfhydril groups of the bacterial wall (Loh et al., 2009) but high dosage of silver particle has toxic effect on the skin cells (Kostenko et al., 2010).

\section{Silver nano particles}

The interaction between the EPS and bacteria plays an important role in the susceptibility of biofilm to the Silver nanoparticles (Ag-NP). Sheng and Liu (2011) found that the viability of the biofilm was reduced after removing the loosely bound EPS from the biofilm but the original waste water biofilm was somewhat tolerant when same amount of the Ag-NP (200mg $\mathrm{Ag} / \mathrm{L}$ ) was added under similar condition. Secinti et al., (2011) studied that the silver coating on the titanium implant can reduce formation of biofilm than the non coated implant. Fabrega (2011) found that Ag particles are effective against natural marine biofilm forming bacteria. Zhang et al., (2012) found that quaternary ammonium dimethacrylate along with silver nanoparticle has potentiated activity against the dental 
plaque microcosm biofilm than using the agent alone, by reducing the biofilm viability when added into the adhesives. Fei et al., (2013) used Bombyx mori silk fibroin as biotemplate to produce silver nanoparticle as it acts as reducing as well as stabilizing agent for silver under incandescent or sunlight at room temperature and showed to be effective against MRSA and subsequently prevented biofilm production by the same bacteria. $\mathrm{Di}$ Giulio et al., (2013) studied the antibacterial activity of nanocomposite system based on lactose substituted chitosen and the silver particles on saliva derived biofilms caused by Streptococcus mitis, S. mutans, S. oralis and found to be promising antibiofilm agent. Loo et al., (2014) formed stable hydrogel incorporating Ag nanoparticles with polyvinyl alcohol where silver particles interacts with the $\mathrm{OH}$ group and acts as non toxic agent on human bronchial epithelial cells was found to have stronger antibiofilm effect on Pseudomonas aeruginosa. Freire et al., (2015) evaluated antibiofilm property of AgNP using parallel-flow cell and dichromatic fluorescent stain system against Streptococcus mutans in dental enamel. Goswami et al., (2015) synthesized Ag-NPs using tea extract and showed to have antibiofilm activity on silicon tubes and polystyrene coverslips with dose dependency disrupting cell-cell adhesion. Hazer et al., (2016) studied antibacterial effect of polymer based Ag-NP coated pedicle screws on MRSA in the surgical sites of rabbit spine and found to be effective in minimizing biofilm formation. Misba et al., (2016) evaluated antibiofilm activity of photosensitizer toluidine blue conjugated with silver naoparticles on Streptococcus mutans by using light and were found to be more phototoxic due to generation of reactive oxygen species hence decreased biofilm formation. Dai et al., (2017) synthesized Silver nanoparticles with different cationic membrane targeting ligands attached on it and studied that it could irreversively disrupt bacterial membrane and inhibit intracellular enzyme activity causing $80 \%$ eradication of drug resistant bacterial biofilm. Malaikozhundan et al., (2017) synthesized Ag-NPs coated with Solanum nigrum fruit extract and found to be effective against biofilm formed by Bacillus pumulis and Enterococcus faecalis. Kumar et al., (2017) biofabricated Silver nano colloid using aqueous Silver nitrate and latex of plants jatropha and Lannea grandis found to be effective against biofilm formed by Candida albicans. Green synthesized silver nanoparticles using Artemisia vulgaris (Kiran et al., 2017) and marine endophytic fungus Penicillium polonicum (Neethu et al., 2018) have been studied to have antibiofilm activity. $\mathrm{Yu}$ et al., (2018) studied the silver nanoparticle decorated quercetin nanoparticles against biofilm formed by Escherichia coli during mastitis and was proved to have stronger antibiofilm activity. Gillett et al., (2018) studied chemical composition of Ag-NP using X-ray photoelectron spectroscopy and $10.6 \mathrm{~nm}$ sized particle was tested against E. coli biofilm formation and found to be effective in slowing initial biofilm formation. Sambalova et al., (2018) found that biopolymer fraction of biofilm organic matrix can reduce ionic silver (Ag) and thus stabilize the formed nano silver and found that the Ag particle biopolymer interface is dominated by carboxylate functional groups. Ogawa et al., (2018) analysed the micro organism in the biofilm of Ag-NP dispersed silane based coated carbon that reduces biofilm formation in sea water using next generation sequencing. Hussain et al., (2019) synthesized silver nanoparticles from Pandanus odorifer leaf extract and it showed MIC of about 4-16 $\mathrm{ug} / \mathrm{ml}$ against both gram positive as well as gram negative bacteria. The exopolysccharide production was decreased by $61-79$ and $84 \%$ in gram negative and gram positive organisms respectively. Vijayakumar et al., (2019) 
evaluated antibacterial as well as antibiofilm activity of garlic clove based silver nanoparticle and found to have excellent antibiofilm activity on MRSA and Pseudomonas aeruginosa at $100 \mathrm{ug} / \mathrm{ml}$. Hamida et al., (2020) synthesized Ag-NP using Desertifilum spp. and evaluated antibacterial activity against five different MRSA strains where it caused denaturation of bacterial cellular proteins and particle induced reactive oxygen species could decrease biofilm formation. Porter et al., (2020) formulated silver nano particle incorporated into glass ionomer cements which was found to reduce bacterial colonization and thus have antibiofilm activity.

\section{Gold nano particles}

It has been studied that gold NPs alone have no or little bacteriocidal activity ( $\mathrm{Yu}$ et al., 2016). Since they are non cytotoxic so can be conjugated with different targeting molecules like active biomolecules, antibiotics to have antibiofilm activity against different multidrug resistant bacteria (W.Y. Chen et al., 2010).

Khan et al., (2012) studied photodynamic therapy of methylene blue conjugated gold particle and found to have type one phototoxicity in the biofilm caused by Candida albicans. Together with other metal oxide like iron oxide gold particles can eradicate biofilm on biomaterial implants (Sathyanarayanan et al., 2013). Au-NP can be used to store and stable release of the nitric oxide in the biofilm dispersal activity (Duong et al., 2014). Sherwani et al., (2015) studied the methylene blue and toluidine blue sensitizers conjugated Au-NPs on Candia albicans biofilms produced in $\mathrm{BALB} / \mathrm{c}$ mice. Boda et al., (2015) tested antibacterial activity of ultra small gold nano particles with core diameters of 0.8 and $1.4 \mathrm{~nm}$ (Au0.8MS and Au1.4MS) against $S$. aureus, S. epidermidis,
E. coli and $P$. aeruginosa which showed $5 \log$ bacterial growth reduction in 5 hours and with two fold increase in the MIC dosage caused $80-90 \%$ reduction in the Staphylococcal biofilm viability. Meeker et al., (2016) studied daptomycin loaded Au-NPs against Staphylococcal biofilm. Ahmed et al., (2016) studied about the activity of Au-NP conjugated to chlorhexidine and found to eradicate the pre formed biofilm formed by Klebsiella pneumoniae. Gold particles conjugated with chitosan-streptomycin is specially useful against biofilms formed by gram negative organisms (Mu et al., 2016). Hu et al., (2017) synthesized surface adaptive Au-NPs by modifying the surface with $\mathrm{pH}$ responsive monolayers targeting acidic environment of the biofilm and found to have photothermal ablation activity on biofilm formed by MRSA. Ahiwale et al., (2017) synthesized gold particles using bacteriophage and found that $0.2 \mathrm{mM}$ of compost could cause $80 \%$ biofilm reduction. The heat dissipated by Gold nano particles due to surface plasmon resonance upon optical irradiation is a new approach to kill bacteria in biofilm (Pihl et al., 2017). Gold stabilized antibiofilm agent cinnamaldehyde can be used as nano construct as singly the compound is unstable (Ramasamy et al., 2017). Lu et al., (2018) evaluated that the imidazole capped chitosan gold particles had enhanced antibacterial effect to prevent biofilm formation. Alteriis et al., (2018) studied peptide indolicidin coated Au-NPs and their application against Candida biofilm. Green synthesis of gold particles from phyto compound baicalein (Rajkumari et al., 2017), hordeinine as reducing and capping agent (Rajkumari et al., 2017), Cannabis sativa (Singh et al., 2018), fruit juice Citrus macroptera as reducing and stabilizing agent (Majumar et al., 2019) were found to have antibiofilm effect. There are other gold particles which are obtained from hydrogenproducing hyperthermophilic bacterial strain 
Caldicellulosiruptor changbaiensis (Bing et al., 2018), rhizome extracts of Rhodiola rosea (Singh et al., 2018) and marine plant $P$. tetrastromatica (Salam et al., 2020) are known to have antibiofilm activity. Zhang et al., (2020) coated the dental aligner with 4,6di amino-2-pyrimidine thiol modified Au-NPs and proved to have the antibiofilm activity against Porphyromonus gingivalis. Bhatia et al., (2020) used Silver-Gold hybrid nonoconstructs against intracellular infection as well as biofilm production.

\section{Copper nanoparticles}

Copper nano particles are seen to have narrow spectrum of antibacterial activity (P.S. Murthy et al., 2011). Their antibacterial activities are less potential as compared to other metals like silver or iron particles hence high concentration is required for effective control (Ren et al., 2009; Esteban et al., 2009).

Akar et al., (2013) tested the antifouling performance of copper by using modified polyetherosulfone filtration membrane dispersed with Copper and selenium particles. Ghasemian et al., (2015) found CuO-NPs to be effective against Listeria monocytogeges biofilm with MIC $16 \mathrm{mg} / \mathrm{L}$ and $67 \%$ hydrophobicity decreasing attachment and colonization. Lewis Oscar et al., (2015) studied $\mathrm{CuO}-\mathrm{NPs}$ and found to be effective against $P$. aeruginosa with MIC $100 \mathrm{ng} / \mathrm{ml}$ and $94 \%$ reduction in biofilm. Wonoputri et al., (2015) studied about the effectiveness of copper complex-nitrite-ascorbic acid system for biofilm control causing increase level of nitric oxide on addition of copper particles. Essa et al., (2016) demonstrated the antibiofilm activity of biological Cu-NPs treated with headspace gases generated by $\mathrm{E}$. coli. Miao et al., (2016) found that CuO-NPs $(50 \mathrm{mg} / \mathrm{L})$ could result in deeper penetration depth of oxygen in biofilm. Suresh et al.,
(2016) studied effective antibiofilm activity of CuNPs using Hydrazine hydrate as reducing agent and Gum kondagogu extract as stabilizing agent. Ashajyothi et al., (2016) studied symbiotic antibiofilm effect of copper and zinc oxide nano particles with minimum inhibitory concentration of about 2$128 \mathrm{ug} / \mathrm{mL}$. Miao et al., (2017) studied the antibiofilm activity of $\mathrm{CuO}$ nanoparticles against waste water biofilm. Pant et al., (2017) fabrigated a polymer composite containing S-nitroso-N-acetylpenicillamine with addition of $\mathrm{Cu}-\mathrm{NPs}$ in carbosil to increase nitric oxide release. Woźniak et a., (2017) synthesized Cu-NPs from peppermint extract using green reduction method and studied the synergistic effect of nanoconstruct loaded rifampicin in biofilm matrix disintegration. Covarrubias et al., (2018) found that copper-chitosan NPs are effective against cariogeneic Streptococcus mutans in dental plaque biofims. Pugazhendhi et al., (2018) analysed the photolytic activity of synthesized iron doped $\mathrm{CuO}$ and found to have antibiofilm activity. Shanan et al., (2018) synthesized Cu-NPs using Eucalyptus camaldulensis and $\mathrm{CuNO} 3$ and found to have excellent antibiofilm activity. Widyńska et al., (2018) found silver nanoparticls to have stronger antibiofilm effect than the $\mathrm{Cu}$-NPs in all concentration. Logpriya et al., (2018) studied antibiofilm effect of chitosan-CuO nano particles and found to have 63\% reduction at $100 \mathrm{ug} / \mathrm{ml}$ against $P$. aeruginosa. Beltrán et al., (2019) studied antibiofilm activity of ascorbic acid capped $\mathrm{Cu}-\mathrm{NPs}$ where ascorbic acid acts as reductant and stabilizer. Arul et al., (2019) studied about the synergistic combination of beta lactum antibiotic amoxyclav with $\mathrm{CuO}$ nanocubes against multi drug resistant bacterial biofilm. Ali et al., (2019) studied terpenoid encapsulated $\mathrm{Cu}-\mathrm{NPs}$ made of Eucalyptus globules leaf extract as reducing as well as stabilizing agent against biofilm through generating reactive oxygen species. Khodair 
et al., (2019) studied the deletion effect of $\mathrm{Cu}-\mathrm{NPs}$ on biofilm gene ElF against Pseudomonas aeruginosa. Singh et al., (2019) studied about the downregulation of genes forming biofilms and membrane lipo protein synthesis damaging the cell surface of Pseudomonas aeruginosa by $\mathrm{Cu}-\mathrm{NPs}$. Wang et al., (2019) studied glycol modified Cu9S8 NPs against implant related biofilm. Rasool et al., (2019) studied the antibiofilm activity against fluconazole resistant Candida albicans biofilm. Lotha et al., (2019) studied about $\mathrm{Cu}-\mathrm{NPs}$ capped with biogenic phytochemicals like cassinopin as well as isoquercitin and their antibiofilm effect against MRSA. Elsayed et al., (2020) found that disinfectant loaded $\mathrm{Cu}-\mathrm{NPs}$ could be used for Staphylococcal biofilm eradication in poultry farm as well as in abattoirs. Punniyakotti et al., (2020) sysnthesized $\mathrm{Cu}$ NPs using Cardiospermum halicacabum leaf extract and it was found to be effective against biofilm formation by attaching the cell wall and inhibit the growth of bacteria.

\section{Zinc nano particles}

Zinc oxide nano particles are known to have better antibacterial properties with low cellular toxicities against organisms like $S$. aureus, S. epidermidis, E. facecalis, $B$. subtilis and E. coli as compared to other metal oxides (Jones et al., 2008; J.H et al., 2014). However, zinc resistance also has been reported for P. aeruginosa and Proteus (B.M et al., 2013; Zhang et al., 2013).

Seil et al., (2011) incorporated ZnO-NPs into polyvinyl chloride, amolymeric biomaterial to study the antibiofilm activity. Dwivedi et al., (2014) studied about characterization and biocidal potential of ZnO-NPs against reactive oxygen species mediated bacterial biofilm. Lee et al., (2014) found that $\mathrm{ZnO}-$ NPs inhibit biofilm formation as well as the production of pyocyanin, pyochelin and haemolytic activity of $P$. aerusinosa. The potential anti bacterial as well as antibiofilm activities of $\mathrm{ZnO}-\mathrm{NPs}$ have been reported in combination with other metals like Silver and zinc dopped mulite ceramic discs (Saleh et al., 2011), sonochemical coating of $\mathrm{CuO}$ and $\mathrm{ZnO}$ NPs against $S$. mutans biofilm formed on tooth (Eshed et al., 2012), Copper and ZnONPs (Khan et al., 2013), of silver and zinc oxide (Patil et al., 2014), Silver and ZnO-NPs against enterotoxic E. coli (Salem et al., 2015), Magnesium doped ZnO-NPs (Iribarnegaray et al., 2019); graphene oxide supported zinc-cobalt oxides with high catalytic activity (Yang et al., 2019), microspheres silver-zinc oxide NPs with polyester surfaces (Fontecha et al., 2020), $\mathrm{ZnO}$ and silver nanopartcles in biofilm of MRSA from burn wound infection (Shakerimoghaddam et a., 2020). Green extract of $\mathrm{ZnO}-\mathrm{NPs}$ have been reported from various sources like Plectranthus amboinicus against MRSA (Vijayakumar 2015), Pseudomonus putida culture (Jayabalan et a., 2019), plant extracts olive leave tomato fruit and tomato fruit (Ogunyemi et a., 2019), sea weed Ulva lactuca (Ishwarya et al., 2018), Aloe vera extract (Ali et al., 2016), aqueous leaf extract of Plectranthus barbatus (Vijayakumar et al., 2017) with effective antibiofilm activities. Abdulkareem et a., (2015) combined $\mathrm{ZnO}$ with hydroxyl appetite coated onto Ti discs and examined on saliva biofim. Xu et al., (2016) compared the toxicity as well as the antibiofilm activity of ZnO-NPs and Zinc ions against Fluvial bioffilm. Cierech et al., (2016) studied polymethylmethacrylate modified $\mathrm{ZnO}-\mathrm{NPs}$ agains fungal biofilm Candida albicans. Jothiprakasam et al., (2017) synthesized ZnONPs from egg albumin and studied the antibiofilm activity against fungus. However, Ouyang et al., (2017) found that mature and intact biofilm is tolerant to $\mathrm{ZnO}-\mathrm{NPs}$, also the environmental constituent humic acid (HA) reduces the toxicity of $\mathrm{ZnO}$ towards biofilm 
by binding HA on Zn ion. Divya et al., (2018) studied gelatin coated $\mathrm{ZnO}-\mathrm{NPs}$ and found to have stronger antibiofilm activity against gram negative organisms than in gram positive organisms. Bhattacharyya et al., (2018) found the anti biofilm activity of $\mathrm{ZnO}$ NPs against S. pneumonia at $12 \mathrm{ug} / \mathrm{ml}$ conc. Shakibaie et al., (2019) studied the non oxidised form of $\mathrm{Zn}$ particle to see the anti biofilm activity using Lavandula vera extract with microwave irradiation. Mehta et al., (2019) studied the therapeutic index as well as the effect of nanomicellar composites containing chitosan and $\mathrm{ZnO}$ against drug resistant bacterial biofilm. El-Shounya (2019) tested antibiofilm activity of Zinc peroxide nanoparticles against multi drug resistant $P$. aeruginosa. Kemung et al., (2020) studied that $\mathrm{ZnO}-\mathrm{NP}$ had effective anti biofilm activity at minimum $13.5 \mathrm{ug} / \mathrm{ml}$ against MRSA showing concentration dependent anti-adherence. Saravanakumar et al., (2020) found that $\mathrm{ZnO}-\mathrm{NPs}$ conjugated to Beta-Dglucan of barley has anti biofilm effect against Trichoderma. Banerjee et al., (2020) studied the antibiofilm activity of pancreatic doped $\mathrm{ZnO}$-NPs against MRSA that are non toxic in bacteriocidal concentration. Hsueh Jing et al., (2020) found excellent anti biofilm property in catheter coating with zinc loaded palygorskite nanocomposites. Janani et al., (2020) evaluated photolytic and anti biofilm activity of Carbon stabilized $\mathrm{ZnO}-\mathrm{NPs}$ and found to be $100 \%$ effective in biofilm inhibition at $10 \mathrm{ug} / \mathrm{L}$ against $\mathrm{S}$.aureus.

\section{Iron nano particles}

Iron oxide nano particles have some unique properties like superparamagnetism, their surface to volume ratio is also high with large biocompatibility as well as easily extractable property (Ranmadugala et al., 2018). Subbiahdoss et al., (2012) studied surface modified SPIONs (superparamagnetic iron oxide-NPs) with magnetically concentrated carboxyl graft and analysed anti biofilm activity against gentamicin resistant Staphylococcus. Anghel et al., (2013) combined FeO-NPs with essential oil secreted by Satureja hortensis and studied antibiofilm effect against Candida albicans. Temperature has impact on biofilm formation, an increase in the temperature by $5^{\circ} \mathrm{C}$ or more can cause detachment of biofilm. Nguyen et al., (2015) induced local hyperthermia by using poly oligo ethylene glycol methyl ethyl acrylate block poly mono acryloxyethylphosphate stabilized FeO-NPs and used against Pseudomonas biofilm to see the dispersion. Masadeh et al., (2015) found that addition of combination of metal nano particles like cerium oxide and iron oxide can interfere with broad spectrum antibiotic like ciprofloxacin. Salman et al., (2015) synthesized FeO-NPs from Lactobacillus fermentum and found to have $33.97 \%$ inhibition against $\mathrm{S}$. aureus and $16.92 \%$ against E. coli. Salman et a., (2015) studied antibiofilm activity of chlorhexidine carrier nanosystem, based on $\mathrm{FeO}$ magnetic NPs and found to have anibiofilm activity at 78ug/mL.

Herrling et al., (2016) studied biosorption of silica coated FeO-NPs on heterophilic biofilm and it was found to be concentration dependent. Velusamy et a., (2016) synthesized oleic acid coated FeO-NPs and found to be more effective against gram positive organisms than in gram negative organisms produced biofilms. Chitosan coated FeO-NPs are found to be effective at $500 \mathrm{ug} / \mathrm{mL}$ concentration (Shi et al., 2016). Geilich et al., (2017) synthesized multicompartment nanocarrier containing both hydrophobic superparamagnetic iron oxide-NPs(SPIONs) and hydrophilic methicillin and found to be effective at $40 \mathrm{ug} / \mathrm{mL}$ SPIONs and $20 \mathrm{ug} / \mathrm{mL}$ antibiotic to eradiate biofilm formation. SPIONs against biofilm were also studied by (Taylor et al., 2009, Taylor et al., 2012, Durmus et al., 
2013, Javanbakht et al., 2016, Al-Shabib et al., 2018). Ramezani et al., (2017) studied super paramagnetic FeO-NPs and found to be effective against strong biofilm produced by $P$. aeruginosa but also reported that FeO-NPs could enhance the biofilm formation in isolate-dependent manner by utilizing the FeO-NPs as iron source for their growth. Kanchana et al., (2018) synthesized FeO-NPs from leaf extracts of Simarauba glauca and Artocarpus artilis and found to have more than $75 \%$ reduction in biofilm within 24 hours and another green extract from grey mangrove Avicennia marina (Ramalingam 2019) also found to have anti biofilm activity. There is evidence that Fe-NPs can induce biofilm formation in certain bacteria like $P$. aeruginosa (Borcherding et a., 2014)but, synthetic nanoparticles like FeOOH-NPs have been proven to disrupt the biofilm architecture in concentration dependent manner in Pseudomonas aeruginosa with modulation of motility and virulence (Pham et al., 2019).

Naha et al., (2019) studied the activity of nanozyme (dextran coated-iron oxide nanoparticles) and found that they were specific in nature to target the acidic environment within the biofilm EPS. Patel et al., (2019) synthesized solid lipid nano particles of silver sulfadiazine loaded with chitosan gel in combination with DNase-I that can degrade the DNAs present in the polymeric substance of biofilm ultimately helps in cell to cell adhesion and found to be effective against biofilm related wound healing complication. Arias et al., (2020) used the chitosan coated FeO-NPs as carrier for miconazole antifungal drug and tested against Candida biofilm. Cusimano et al., (2020) synthesized biogenic nanoparticles embedding the Ag-NPs with peculiar EPS and then added iron nano particles onto it and found to have anti biofilm activity due to release of silver ions in low Fe/Ag-EPS.

\section{Titanium nano particles}

$\mathrm{TiO} 2$ acts as photocatalyst and due to its inert nature it is considered to be non toxic metal oxide, hence safe for application. Different antimicrobial actions involved are oxidation of several internal enzymes, peroxidation of lipids thus generating reactive oxygen species in the micro organisms leading to cell death (Y.Ohko et al., 2009).

Chorianopoulos et al., (2011) studied photocatalytic activity of TiO2-NPs against Listeria monocytogenes and it showed fastest $\log$ reduction in the of bacterial biofilm i.e. 3 $\log \mathrm{CFU} / \mathrm{cm}^{2}$ after $90 \mathrm{~min}$. Dhandapani et al., (2012) studied photo catalytic activity of TiO2-NPs by fixing it on glass slide and allowed to grow biofilm on it, found to have good photo catalyst by generating hydrogen peroxide on the interface. Khan et al., (2013) studied photocatalytic activity of $\mathrm{TiO} 2$ decorated silver nanocomposite using electro chemically active biofilm. Schug et al., (2014) studied the activity of TiO2-NPs with UV radiation on extracellular enzymes in the biofilm like $\beta$-glucosidase and L- leucin aminopeptidase and found to have reduced activity due to generation of ROS. Naik et al., (2014) studied $\mathrm{AgCl}-\mathrm{TiO}_{2} \mathrm{NPs}$ and found to have anti biofilm activity where titanium helps in controlled sustainable release of $\mathrm{Ag}$ particles. Jesline et al., (2015) studied antibiofilm activity of $\mathrm{TiO}_{2}$-NPs on MRSA and found to have maximum zone of inhibition of $14 \mathrm{~mm}$ at $500 \mathrm{ug} / \mathrm{mL}$ and minimum zone of inhibition of 11 and $12 \mathrm{~mm}$ at $100 \mathrm{ug} / \mathrm{mL}$. Kamaraj et al., (2015) evaluated anti biofilm effect of silver nano particle loaded $\mathrm{TiO}_{2}$-NPs against Pseudomonas and Bacillus spp. Jomini et al., (2015) tested the TiO2-NPs against both sessile as well as planktonic stage of bacterial community. Xiao et al., (2016) evaluated the anti biofilm activity of TiO2-NPs against E. coli biofilm and found that it generated reactive oxygen 
species which further quenched auto inducer signals needed for quorum sensing phenomenon as well as suppressed expression of other genes like motA and rcsB required for biofilm formation. Khan et al., (2016) used combination of $\mathrm{ZnO}$ and $\mathrm{TiO}_{2}$ nano particles against Streptococcus mitis biofilm and found to be effective at very low conc i.e. IC value $37 \mathrm{ug} / \mathrm{mL}$ for $\mathrm{ZnO}-\mathrm{NPs}$ and 77 $\mathrm{ug} / \mathrm{mL}$ for $\mathrm{TiO}_{2}$-NPS by inducing oxidative stress.

Biswas et al., (2017) studied TiO2-graphene quantum dot hybrid material in presence of UV light, which was found to have stronger photocatalytic activity in compared to $\mathrm{TiO} 2$ due to generation of reactive oxygen species. De Falco et al., (2017) studied flame synthesized nanocomposite having $\mathrm{TiO}_{2}$ coating on aluminium substrate and found to have antibiofilm activity due to photo oxidation in presence of UV light. Lopes et al., (2017) used Titanium oxide nano-particles on diamond like carbon film used on several medical implants to reduce the oxidation of the implant material as well as to reduce bacterial biofilm. Dias et al., (2019) synthesized $\mathrm{TiO} 2$ and $\mathrm{TiO} 2 / \mathrm{Ag}$ NPs using microwave assisted hydrothermal method against Streptococcus mutans biofilm formation on resin surface.

Rajkumari et al., (2019) tested the antibiofilm activity of $\mathrm{TiO}_{2}$-NPs produced by the leaf extract of Aloe barbadensis after exposing the metabolic activity of Pseudomonas aeruginosa with $\mathrm{MIC}$ of $\mathrm{TiO}_{2}$-NPs. Noreen et al., (2019) synthesized nano composite combining $\mathrm{Ag} / \mathrm{TiO}_{2} /$ grapheme and found to be effective against Campylobacter biofilm reducing the motility, hydrophobicity and self aggregation of C. Jejuni. Hou et al., (2019) tested the $\mathrm{TiO}_{2}-\mathrm{NPs}$ on periphytic biofilm and found that the metabolic activity like production of protein within the EPS was increased but the extracellular enzyme activity of alkali phosphatase was decreased when exposed to $1-5 \mathrm{mg} / \mathrm{L} \mathrm{TiO}_{2}$-NPs.

In conclusion it is discussed in this review that nano technology plays a key role in creating different novel approaches to prevent and control biofilm formation. Several researches are being carried out to create different bio active compounds using metal oxide nano particles which target one or multiple species of pathogens. These metal oxide nano particles are proved to have bacteriocidal properties with minimum or no toxicity and hence safe for use specially to combat the emergence of antibiotic as well as multidrug resistance related problems. These can be synthesized from different sources including green source like leaf extracts and used as coating or drug carrier. Although different metal nano particles have been developed as novel anti biofilm agents but people fail to adopt them because of high cost involvement therefore, scientists are looking for alternative approach available considering the cost issue. Moreover, in future the risk of possibility of emergence of resistance against these metal nano particles should be analyzed thoroughly and the interaction among the particles, interface and host also should be taken into consideration for effective control of biofilm against different infectious agents.

\section{References}

Abdulkareem, E. H., Memarzadeh, K., Allaker, R. P., Huang, J., Pratten, J., and Spratt, D. 2015. Antibiofilm activity of zinc oxide and hydroxyapatite nanoparticles as dental implant coating materials. Journal of dentistry, 43(12), 1462-1469.

Ahiwale, S. S., Bankar, A. V., Tagunde, S., and Kapadnis, B. P. 2017. A bacteriophage mediated gold nanoparticles synthesis and their anti-biofilm activity. Indian journal of microbiology, 57(2), 188-194.

Ahmed, A., Khan, A. K., Anwar, A., Ali, S. A., and Shah, M. R. 2016. Biofilm inhibitory effect of chlorhexidine conjugated gold nanoparticles against Klebsiella pneumoniae. Microbial pathogenesis, 98, 50-56. 
Akar, N., Asar, B., Dizge, N., and Koyuncu, I. 2013. Investigation of characterization and biofouling properties of PES membrane containing selenium and copper nanoparticles. Journal of Membrane Science, 437, 216-226.

Ali, K., Ahmed, B., Ansari, S. M., Saquib, Q., AlKhedhairy, A. A., Dwivedi, S., and Musarrat, J. 2019. Comparative in situ ROS mediated killing of bacteria with bulk analogue, Eucalyptus leaf extract (ELE)-capped and bare surface copper oxide nanoparticles. Materials Science and Engineering: C, 100, 747-758.

Ali, K., Dwivedi, S., Azam, A., Saquib, Q., Al-Said, M. S., Alkhedhairy, A. A., and Musarrat, J. 2016. Aloe vera extract functionalized zinc oxide nanoparticles as nanoantibiotics against multi-drug resistant clinical bacterial isolates. Journal of colloid and interface science, 472, 145-156.

Al-Shabib, N. A., Husain, F. M., Ahmed, F., Khan, R. A., Khan, M. S., Ansari, F. A., and Khan, J. M. 2018. Low temperature synthesis of superparamagnetic iron oxide (Fe3O4) nanoparticles and their ROS mediated inhibition of biofilm formed by food-associated bacteria. Frontiers in microbiology, 9, 2567.

Anghel, I., Grumezescu, A. M., Holban, A. M., Ficai, A., Anghel, A. G., and Chifiriuc, M. C. 2013. Biohybrid nanostructured iron oxide nanoparticles and Satureja hortensis to prevent fungal biofilm development. International journal of molecular sciences, 14(9), 18110-18123.

Arias, L. S., Pessan, J. P., de Souza Neto, F. N., de Lima, B. H. R., de Camargo, E. R., Ramage, G., and Monteiro, D. R. 2020. Novel nanocarrier of miconazole based on chitosan-coated iron oxide nanoparticles as a nanotherapy to fight Candida biofilms. Colloids and Surfaces B: Biointerfaces, 111080.

Arul Selvaraj, R. C., Rajendran, M., and Nagaiah, H. P. 2019. Re-Potentiation of $\beta$-Lactam Antibiotic by Synergistic Combination with Biogenic Copper Oxide Nanocubes against Biofilm Forming Multidrug-Resistant Bacteria. Molecules, 24(17), 3055.

Ashajyothi, C., Harish, K. H., Dubey, N., and Chandrakanth, R. K. 2016. Antibiofilm activity of biogenic copper and zinc oxide nanoparticlesantimicrobials collegiate against multiple drug resistant bacteria: a nanoscale approach. Journal of Nanostructure in Chemistry, 6(4), 329-341.

Banerjee, S., Vishakha, K., Das, S., Dutta, M., Mukherjee, D., Mondal, J. and Ganguli, A. 2020. Antibacterial, anti-biofilm activity and mechanism of action of pancreatin doped zinc oxide nanoparticles against methicillin resistant Staphylococcus aureus. Colloids and Surfaces B:
Biointerfaces, 110921.

Beltrán-Partida, E., Valdez-Salas, B., Valdez-Salas, E., Pérez-Cortéz, G., and Nedev, N. 2019. Synthesis, characterization, and in situ antifungal and cytotoxicity evaluation of ascorbic acid-capped copper nanoparticles. Journal of Nanomaterials, 2019.

Bhatia, E., and Banerjee, R. 2020. Hybrid silver-gold nanoparticles suppress drug resistant polymicrobial biofilm formation and intracellular infection. Journal of Materials Chemistry B, 8(22), 4890-4898.

Bhattacharyya, P., Agarwal, B., Goswami, M., Maiti, D., Baruah, S., and Tribedi, P. 2018. Zinc oxide nanoparticle inhibits the biofilm formation of Streptococcus pneumoniae. Antonie Van Leeuwenhoek, 111(1), 89-99.

Bing, W., Sun, H., Wang, F., Song, Y., and Ren, J. 2018. Hydrogen-producing hyperthermophilic bacteria synthesized size-controllable fine gold nanoparticles with excellence for eradicating biofilm and antibacterial applications. Journal of Materials Chemistry B, 6(28), 4602-4609.

Biswas, A., Salunke, G., Khandelwal, P., Das, R., and Poddar, P. 2017. Surface disordered rutile TiO 2graphene quantum dot hybrids: a new multifunctional material with superior photocatalytic and biofilm eradication properties. New Journal of Chemistry, 41(7), 2642-2657.

Boda, S. K., Broda, J., Schiefer, F., Weber- Heynemann, J., Hoss, M., Simon, U., and Jahnen- Dechent, W. 2015. Cytotoxicity of ultrasmall gold nanoparticles on planktonic and biofilm encapsulated gram- positive staphylococci. Small, 11(26), 3183-3193.

Borcherding, J., Baltrusaitis, J., Chen, H., Stebounova, L., Wu, C. M., Rubasinghege, G., and Comellas, A. P. 2014. Iron oxide nanoparticles induce Pseudomonas aeruginosa growth, induce biofilm formation, and inhibit antimicrobial peptide function. Environmental Science: Nano, 1(2), 123132.

Chaudhari, P. R., Masurkar, S. A., Shidore, V. B., and Kamble, S. P. 2012. Effect of biosynthesized silver nanoparticles on Staphylococcus aureus biofilm quenching and prevention of biofilm formation. Nano-Micro Letters, 4(1), 34-39.

Chorianopoulos, N. G., Tsoukleris, D. S., Panagou, E. Z., Falaras, P., and Nychas, G. J. 2011. Use of titanium dioxide (TiO2) photocatalysts as alternative means for Listeria monocytogenes biofilm disinfection in food processing. Food Microbiology, 28(1), 164-170.

Cierech, M., Kolenda, A., Grudniak, A. M., Wojnarowicz, J., Woźniak, B., Gołaś, M.,. and Mierzwińska-Nastalska, E. 2016. Significance of 
polymethylmethacrylate (PMMA) modification by zinc oxide nanoparticles for fungal biofilm formation. International journal of pharmaceutics, 510(1), 323-335.

Costerton JW, Lewandowski Z, Caldwell DE, Korber DR, LappinScott HM. 1995 Microbial biofilms. Annu Rev Microbiol, 49:711-745.

Costerton, J.W. 1999. Bacterial biofilms: a common cause of persistent infections, Science 284, 1318 1322.

Costerton, J.W.; Geesey, G.G.; Cheng, K.J. Howbacteriastick. 1978. Sci. Am., 238, 86-95.

Covarrubias, C., Trepiana, D., and Corral, C. 2018. Synthesis of hybrid copper-chitosan nanoparticles with antibacterial activity against cariogenic Streptococcus mutans. Dental materials journal, 37(3), 379-384.

Cusimano, M. G., Ardizzone, F., Nasillo, G., Gallo, M., Sfriso, A., Martino-Chillura, D., and Gallo, G. 2020. Biogenic iron-silver nanoparticles inhibit bacterial biofilm formation due to $\mathrm{Ag}+$ release as determined by a novel phycoerythrin-based assay. Applied Microbiology and Biotechnology.

Dai, X., Chen, X., Zhao, J., Zhao, Y., Guo, Q., Zhang, T., and Li, C. 2017. Structure-activity relationship of membrane-targeting cationic ligands on a silver nanoparticle surface in an antibiotic-resistant antibacterial and antibiofilm activity assay. ACS Applied Materials and Interfaces, 9(16), 1383713848.

Davies, D. G., M. R. Parsek, J. P. Pearson, B. H. Iglewski, J. W. Costerton and E. P. Greenberg.1998. "The involvement of cell-to-cell signals in the development of a bacterial biofilm." Science 280(5361): 295-298.

de Alteriis, E., Maselli, V., Falanga, A., Galdiero, S., Di Lella, F. M., Gesuele, R., and Galdiero, E. 2018. Efficiency of gold nanoparticles coated with the antimicrobial peptide indolicidin against biofilm formation and development of Candida spp. clinical isolates. Infection and drug resistance, 11,915 .

De Falco, G., Porta, A., Petrone, A. M., Del Gaudio, P., El Hassanin, A., Commodo, M., and D'Anna, A. 2017. Antimicrobial activity of flame-synthesized nano-TiO 2 coatings. Environmental Science: Nano, 4(5), 1095-1107.

Decho, A. W.2010. "Overview of biopolymer-induced mineralization: what goes on in biofilms?" Ecological Engineering 36(2): 137-144.

Dhandapani, P., Maruthamuthu, S., and Rajagopal, G. 2012. Bio-mediated synthesis of $\mathrm{TiO} 2$ nanoparticles and its photocatalytic effect on aquatic biofilm. Journal of Photochemistry and Photobiology B: Biology, 110, 43-49.

Di Giulio, M., Di Bartolomeo, S., Di Campli, E.,
Sancilio, S., Marsich, E., Travan, A., and Cellini, L. 2013. The effect of a silver nanoparticle polysaccharide system on streptococcal and salivaderived biofilms. International journal of molecular sciences, 14(7), 13615-13625.

Dias, H. B., Bernardi, M. I. B., Bauab, T. M., Hernandes, A. C., and de Souza Rastelli, A. N. 2019. Titanium dioxide and modified titanium dioxide by silver nanoparticles as an anti biofilm filler content for composite resins. Dental Materials, 35(2), e36-e46.

Divya, M., Vaseeharan, B., Abinaya, M., Vijayakumar, S., Govindarajan, M., Alharbi, N. S., and Benelli, G. 2018. Biopolymer gelatin-coated zinc oxide nanoparticles showed high antibacterial, antibiofilm and anti-angiogenic activity. Journal of Photochemistry and Photobiology B: Biology, 178, 211-218.

Donlan RM, Costerton JW.2002. Biofilms: survival mechanisms of clinically relevant microorganisms. Clin. Microbiol. Rev. 15(2), 167-193.

Duong, H. T., Adnan, N. N. M., Barraud, N., Basuki, J. S., Kutty, S. K., Jung, K., and Boyer, C. 2014. Functional gold nanoparticles for the storage and controlled release of nitric oxide: applications in biofilm dispersal and intracellular delivery. Journal of Materials Chemistry B, 2(31), 50035011.

Durmus, N. G., Taylor, E. N., Kummer, K. M., and Webster, T. J. 2013. Enhanced efficacy of superparamagnetic iron oxide nanoparticles against antibiotic- resistant biofilms in the presence of metabolites. Advanced materials, 25(40), 5706-5713.

Dwivedi, S., Wahab, R., Khan, F., Mishra, Y. K., Musarrat, J., and Al-Khedhairy, A. A. 2014. Reactive oxygen species mediated bacterial biofilm inhibition via zinc oxide nanoparticles and their statistical determination. PloS one, 9(11), e111289.

Ejaz, K., Sadia, H., Zia, G., Nazir, S., Raza, A., Ali, S., and Andleeb, S. 2017. Biofilm reduction, cell proliferation, anthelmintic and cytotoxicity effect of green synthesised silver nanoparticle using Artemisia vulgaris extract. IET Nanobiotechnology, 12(1), 71-77.

Elsayed, M. M., Elgohary, F. A., Zakaria, A. I., Elkenany, R. M., and EL-Khateeb, A. Y. (2020). Novel eradication methods for Staphylococcus aureus biofilm in poultry farms and abattoirs using disinfectants loaded onto silver and copper nanoparticles. Environmental Science and Pollution Research, 1-13.

El-Shounya, W. A., Moawad, M., Haider, A. S., Ali, S., and Nouh, S. 2019. Antibacterial Potential of a Newly Synthesized Zinc Peroxide Nanoparticles 
(ZnO2-NPs) to Combat Biofilm-Producing MultiDrug Resistant Pseudomonas aeruginosa. Egyptian Journal of Botany, 59(3), 657-666.

Eshed, M., Lellouche, J., Matalon, S., Gedanken, A., and Banin, E. 2012. Sonochemical coatings of $\mathrm{ZnO}$ and $\mathrm{CuO}$ nanoparticles inhibit Streptococcus mutans biofilm formation on teeth model. Langmuir, 28(33), 12288-12295.

Essa, A. M., and Khallaf, M. K. 2016. Antimicrobial potential of consolidation polymers loaded with biological copper nanoparticles. BMC microbiology, 16(1), 1-8.

Fabrega, J., Zhang, R., Renshaw, J. C., Liu, W. T., and Lead, J. R. 2011. Impact of silver nanoparticles on natural marine biofilm bacteria. Chemosphere, 85(6), 961-966.

Fei, X., Jia, M., Du, X., Yang, Y., Zhang, R., Shao, Z., and Chen, X. 2013. Green synthesis of silk fibroinsilver nanoparticle composites with effective antibacterial and biofilm-disrupting properties. Biomacromolecules, 14(12), 4483-4488.

Flemmig, T. F.; Beikler,2011. T. Control of Oral Biofilms. Periodontology 2000, 55,9-15.

Fontecha-Umaña, F., Ríos-Castillo, A. G., RipollesAvila, C., and Rodríguez-Jerez, J. J. 2020. Antimicrobial Activity and Prevention of Bacterial Biofilm Formation of Silver and Zinc Oxide Nanoparticle-Containing Polyester Surfaces at Various Concentrations for Use. Foods, 9(4), 442.

Freire, P. L., Stamford, T. C., Albuquerque, A. J., Sampaio, F. C., Cavalcante, H. M., Macedo, R. O., and Rosenblatt, A. 2015. Action of silver nanoparticles towards biological systems: cytotoxicity evaluation using hen's egg test and inhibition of Streptococcus mutans biofilm formation. International journal of antimicrobial agents, 45(2), 183-187.

G.Ren,D.Hu,E.W.C.Cheng,M.A.Vargas-Reus, P. Reip, and R. P. Allaker. 2009. "Characterisation of copper oxide nanoparticles for antimicrobial applications, "International Journal of Antimicrobial Agents, vol.33, no.6, pp. 587-590.

Geilich, B. M., Gelfat, I., Sridhar, S., van de Ven, A. L., and Webster, T. J. 2017. Superparamagnetic iron oxide-encapsulating polymersome nanocarriers for biofilm eradication. Biomaterials, 119, 78-85.

Geilich, B.M. and T.J. Webster, "Reduced adhesion of Staphylococcus aureus to $\mathrm{ZnO} / \mathrm{PVC}$ nanocomposites, "in Proceedings of the 39th Annual Northeast Bioengineering Conference (NEBEC '13), pp.7-8, IEEE, Syracuse, NY, USA, April 2013.

Ghasemian, E., Naghoni, A., Rahvar, H., Kialha, M., and Tabaraie, B. 2015. Evaluating the effect of copper nanoparticles in inhibiting Pseudomonas aeruginosa and Listeria monocytogenes biofilm formation. Jundishapur journal of microbiology, $8(5)$.

Gillett, A. R., Baxter, S. N., Hodgson, S. D., Smith, G. C., and Thomas, P. J. 2018. Using sub-micron silver-nanoparticle based films to counter biofilm formation by Gram-negative bacteria. Applied Surface Science, 442, 288-297.

Goswami, S. R., Sahareen, T., Singh, M., and Kumar, S. 2015. Role of biogenic silver nanoparticles in disruption of cell-cell adhesion in Staphylococcus aureus and Escherichia coli biofilm. Journal of Industrial and Engineering Chemistry, 26, 73-80.

H.J. Busscher and A.H. Weerkamp,1987. Specific and nonspecific interactions in bacterial adhesion to solid substrata, Fems Microbiol. Rev. 46(2), pp. 165-173.

Hall-Stoodley, L.; Costerton, J. W.; Stoodley, P.2004. Bacterial Biofilms: From the Natural Environment to Infectious Diseases. Nat. Rev. Microbiol, 2, 95-108.

Hamida, R. S., Ali, M. A., Goda, D. A., Khalil, M. I., and Al-Zaban, M. I. 2020. Novel Biogenic Silver Nanoparticle-Induced Reactive Oxygen Species Inhibit the Biofilm Formation and Virulence Activities of Methicillin-Resistant Staphylococcus aureus (MRSA) Strain. Frontiers in bioengineering and biotechnology, 8 .

Hannig C, Hannig M 2009. The oral cavity - a key system to understand substratum-dependent bioadhesion on solid surfaces in man. Clin Oral Investig 13:123-139.

Hazer, D. B., Sakar, M., Dere, Y., Altinkanat, G., Ziyal, M. I., and Hazer, B. 2016. Antimicrobial effect of polymer-based silver nanoparticle coated pedicle screws: experimental research on biofilm inhibition in rabbits. Spine, 41(6), E323-E329.

Herrling, M. P., Lackner, S., Tatti, O., Guthausen, G., Delay, M., Franzreb, M., and Horn, H. 2016. Short and long term biosorption of silica-coated iron oxide nanoparticles in heterotrophic biofilms. Science of The Total Environment, 544, 722-729.

Holban, A.M., Lazar, V., 2011. Inter-kingdom crosstalk: the example of prokaryotes- eukaryotes communication. Biointerface Res. Appl. Chem. 1(3).95-110.

Hou, J., Li, T., Miao, L., You, G., Xu, Y., and Liu, S. 2019. Effects of titanium dioxide nanoparticles on algal and bacterial communities in periphytic biofilms. Environmental Pollution, 251, 407-414.

Hsueh, Y. H., Ke, W. J., Hsieh, C. T., Lin, K. S., Tzou, D. Y., and Chiang, C. L. 2015. ZnO nanoparticles affect Bacillus subtilis cell growth and biofilm formation. PloS one, 10(6), e0128457.

Hu, D., Li, H., Wang, B., Ye, Z., Lei, W., Jia, F., and Ji, J. 2017. Surface-adaptive gold nanoparticles 
with effective adherence and enhanced photothermal ablation of methicillin-resistant Staphylococcus aureus biofilm. ACS nano, 11(9), 9330-9339.

Huang, C. Y., S. P. Hsieh, P. A. Kuo, W. N. Jane, J. Tu, Y. N. Wang and C. H. Ko.2009. "Impact of disinfectant and nutrient concentration on growth and biofilm formation for a Pseudomonas strain and the mixed cultures from a fine papermachine system." International Biodeterioration and Biodegradation 63(8): 998-1007.

Hussain, A., Alajmi, M. F., Khan, M. A., Pervez, S. A., Ahmed, F., Amir, S., and Khan, R. A. 2019. Biosynthesized silver nanoparticle (AgNP) from Pandanus odorifer leaf extract exhibits antimetastasis and anti-biofilm potentials. Frontiers in microbiology, 10, 8.

Iribarnegaray, V., Navarro, N., Robino, L., Zunino, P., Morales, J., and Scavone, P. 2019. Magnesiumdoped zinc oxide nanoparticles alter biofilm formation of Proteus mirabilis. Nanomedicine, 14(12), 1551-1564.

Ishwarya, R., Vaseeharan, B., Kalyani, S., Banumathi, B., Govindarajan, M., Alharbi, N. S., and Benelli, G. 2018. Facile green synthesis of zinc oxide nanoparticles using Ulva lactuca seaweed extract and evaluation of their photocatalytic, antibiofilm and insecticidal activity. Journal of Photochemistry and Photobiology B: Biology, 178, 249-258.

Janani, B., Syed, A., Raju, L. L., Al-Harthi, H. F., Thomas, A. M., Das, A., and Khan, S. S. 2020. Synthesis of Carbon Stabilized Zinc Oxide Nanoparticles and Evaluation of Its Photocatalytic, Antibacterial and Anti-biofilm Activities. Journal of Inorganic and Organometallic Polymers and Materials, 30(6), 2279-2288.

Javanbakht, T., Laurent, S., Stanicki, D., and Wilkinson, K. J. 2016. Relating the surface properties of superparamagnetic iron oxide nanoparticles (SPIONs) to their bactericidal effect towards a biofilm of Streptococcus mutans. PLoS One, 11(4), e0154445.

Jayabalan, J., Mani, G., Krishnan, N., Pernabas, J., Devadoss, J. M., and Jang, H. T. 2019. Green biogenic synthesis of zinc oxide nanoparticles using Pseudomonas putida culture and its In vitro antibacterial and anti-biofilm activity. Biocatalysis and Agricultural Biotechnology, 21, 101327.

Jesline, A., John, N. P., Narayanan, P. M., Vani, C., and Murugan, S. 2015. Antimicrobial activity of zinc and titanium dioxide nanoparticles against biofilm-producing methicillin-resistant Staphylococcus aureus. Applied Nanoscience, 5(2), 157-162.

Jing, Y., Mu, B., Zhang, M., Wang, L., Zhong, H., Liu,
X., and Wang, A. 2020. Zinc-loaded palygorskite nanocomposites for catheter coating with excellent antibacterial and anti-biofilm properties. Colloids and Surfaces A: Physicochemical and Engineering Aspects, 124965.

Jomini, S., Clivot, H., Bauda, P., and Pagnout, C. 2015. Impact of manufactured $\mathrm{TiO}_{2}$ nanoparticles on planktonic and sessile bacterial communities. Environmental Pollution, 202, 196-204.

Jothiprakasam, V., Sambantham, M., Chinnathambi, S., and Vijayaboopathi, S. 2017. Candida tropicalis biofilm inhibition by $\mathrm{ZnO}$ nanoparticles and EDTA. Archives of Oral Biology, 73, 21-24.

Kamaraj, K., George, R. P., Anandkumar, B., Parvathavarthini, N., and Mudali, U. K. 2015. A silver nanoparticle loaded $\mathrm{TiO}_{2}$ nanoporous layer for visible light induced antimicrobial applications. Bioelectrochemistry, 106, 290-297.

Kanchana, R., and Zantye, P. 2018. Synthesis, characterization and applications of biogenic iron oxide nanoparticles. International Journal for Research in Applied Science and Engineering Technology, 3, 709-716.

Kemung, H. M., Tan, L. T. H., Khaw, K. Y., Ong, Y. S., Chan, C. K., Low, D. Y. S., and Goh, B. H. 2020. An Optimized Anti-adherence and Antibiofilm Assay: Case Study of Zinc Oxide Nanoparticles versus MRSA Biofilm. Progress In Microbes and Molecular Biology, 3(1).

Keren I, Shah D, Spoering A, Kaldalu N, Lewis K. 2004. Specialized persister cells and the mechanism of multidrug tolerance in Escherichia coli. J Bacteriol.; 186(24):8172-8180.

Khalid, H. F., Tehseen, B., Sarwar, Y., Hussain, S. Z., Khan, W. S., Raza, Z. A. and Rehman, A. 2019. Biosurfactant coated silver and iron oxide nanoparticles with enhanced anti-biofilm and antiadhesive properties. Journal of hazardous materials, 364, 441-448.

Khan, M. M., Ansari, S. A., Amal, M. I., Lee, J., and Cho, M. H. 2013. Highly visible light active Ag@ TiO 2 nanocomposites synthesized using an electrochemically active biofilm: a novel biogenic approach. Nanoscale, 5(10), 4427-4435.

Khan, S. T., Ahamed, M., Al-Khedhairy, A., and Musarrat, J. 2013. Biocidal effect of copper and zinc oxide nanoparticles on human oral microbiome and biofilm formation. Materials Letters, 97, 67-70.

Khan, S. T., Ahmad, J., Ahamed, M., Musarrat, J., and Al-Khedhairy, A. A. 2016. Zinc oxide and titanium dioxide nanoparticles induce oxidative stress, inhibit growth, and attenuate biofilm formation activity of Streptococcus mitis. JBIC Journal of Biological Inorganic Chemistry, 21(3), 295-303. 
Khan, S., Alam, F., Azam, A., and Khan, A. U. 2012. Gold nanoparticles enhance methylene blueinduced photodynamic therapy: a novel therapeutic approach to inhibit Candida albicans biofilm. International journal of nanomedicine, 7, 3245.

Khodair, Z. T., Alzubaidy, M. W. M., Almohaidi, A. M. S., Sultan, A. A., AL-Shimmary, S. M., and Albusultan, S. S. 2019. Synthesis of copper oxide nanoparticles (CuO-NPs) and its evaluation of antibacterial activity against $P$. aeruginosa biofilm gene's. In AIP Conference Proceedings (Vol. 2190, No. 1, p. 020006). AIP Publishing LLC.

Kostenko, V., J. Lyczak, K. Turner and R.J. Martinuzzi, 2010 "Impact of silver-containing wound dressings on bacterial biofilm viability and susceptibility to antibiotics during prolonged treatment," Antimicrobial Agents and Chemotherapy, vol. 54, no. 12, pp. 5120-5131.

Kumar, S., Bhattacharya, W., Singh, M., Halder, D., and Mitra, A. 2017. Plant latex capped colloidal silver nanoparticles: a potent anti-biofilm and fungicidal formulation. Journal of Molecular Liquids, 230, 705-713.

L.Esteban-Tejeda, F.Malpartida, A.Esteban-Cubillo, C.Pecharromn, and J.S. Moya. 2009. "Antibacterial and antifungal activity of a sodalime glass containing copper nanoparticles, "Nanotechnology,vol.20,no.50,ArticleID505701,.

Lee, J. H., Kim, Y. G., Cho, M. H., and Lee, J. 2014. $\mathrm{ZnO}$ nanoparticles inhibit Pseudomonas aeruginosa biofilm formation and virulence factor production. Microbiological research, 169(12), 888-896.

Lee, J.-H., Y.-G. Kim, M.H. Cho, and J. Lee. 2014. " $\mathrm{ZnO}$ nanoparticles inhibit Pseudomonas aeruginosa biofilm formation and virulencefactorproduction,"MicrobiologicalResear ch,vol.169,no. 12,pp.888-896.

LewisOscar, F., MubarakAli, D., Nithya, C., Priyanka, R., Gopinath, V., Alharbi, N. S., and Thajuddin, N. 2015. One pot synthesis and anti-biofilm potential of copper nanoparticles (CuNPs) against clinical strains of Pseudomonas aeruginosa. Biofouling, 31(4), 379-391.

Logpriya, S., Bhuvaneshwari, V., Vaidehi, D., SenthilKumar, R. P., Malar, R. N., Sheetal, B. P., and Kalaiselvi, M. 2018. Preparation and characterization of ascorbic acid-mediated chitosan-copper oxide nanocomposite for antimicrobial, sporicidal and biofilm-inhibitory activity. Journal of Nanostructure in Chemistry, 8(3), 301-309.

Loh, J. V., S. L. Percival, E. J. Woods, N. J. Williams, and C.A. Cochrane. 2009. "Silver resistance in MRSA isolated from wound and nasal sources in humans and animals," International Wound Journal, vol. 6, no.1, pp. 32-38.

Loo, C. Y., Young, P. M., Lee, W. H., Cavaliere, R., Whitchurch, C. B., and Rohanizadeh, R. 2014. Non-cytotoxic silver nanoparticle-polyvinyl alcohol hydrogels with anti-biofilm activity: designed as coatings for endotracheal tube materials. Biofouling, 30(7), 773-788.

Lopes, F. S., Oliveira, J. R., Milani, J., Oliveira, L. D., Machado, J. P. B., Trava-Airoldi, V. J., and Marciano, F. R. 2017. Biomineralized diamondlike carbon films with incorporated titanium dioxide nanoparticles improved bioactivity properties and reduced biofilm formation. Materials Science and Engineering: C, 81, 373379.

Lotha, R., Shamprasad, B. R., Sundaramoorthy, N. S., Nagarajan, S., and Sivasubramanian, A. 2019. Biogenic phytochemicals (cassinopin and isoquercetin) capped copper nanoparticles (ISQ/CAS@ CuNPs) inhibits MRSA biofilms. Microbial pathogenesis, 132, 178-187.

Lu, B., Lu, F., Ran, L., Yu, K., Xiao, Y., Li, Z., and Lan, G. 2018. Imidazole-molecule-capped chitosan-gold nanocomposites with enhanced antimicrobial activity for treating biofilm-related infections. Journal of colloid and interface science, 531, 269-281.

Majumdar, M., Biswas, S. C., Choudhury, R., Upadhyay, P., Adhikary, A., Roy, D. N., and Misra, T. K. 2019. Synthesis of Gold Nanoparticles Using Citrus macroptera Fruit Extract: Anti- Biofilm and Anticancer Activity. ChemistrySelect, 4(19), 5714-5723.

Malaikozhundan, B., Vijayakumar, S., Vaseeharan, B., Jenifer, A. A., Chitra, P., Prabhu, N. M., and Kannapiran, E. 2017. Two potential uses for silver nanoparticles coated with Solanum nigrum unripe fruit extract: biofilm inhibition and photodegradation of dye effluent. Microbial pathogenesis, 111, 316-324.

Marsh, P. D.; Moter, A.; Devine, D. A. 2011. Dental Plaque Biofilms: Communities, Conflict and Control. Periodontology 2000, 55, 16-35.

Masadeh, M. M., Karasneh, G. A., Al-Akhras, M. A., Albiss, B. A., Aljarah, K. M., Al-Azzam, S. I., and Alzoubi, K. H. 2015. Cerium oxide and iron oxide nanoparticles abolish the antibacterial activity of ciprofloxacin against gram positive and gram negative biofilm bacteria. Cytotechnology, 67(3), 427-435.

Meeker, D. G., Jenkins, S. V., Miller, E. K., Beenken, K. E., Loughran, A. J., Powless, A. and Chen, J. 2016. Synergistic photothermal and antibiotic killing of biofilm-associated Staphylococcus aureus using targeted antibiotic-loaded gold 
nanoconstructs. ACS infectious diseases, 2(4), 241250.

Mehta, M., Allen-Gipson, D., Mohapatra, S., Kindy, M., and Limayem, A. 2019. Study on the therapeutic index and synergistic effect of Chitosan-zinc oxide nanomicellar composites for drug-resistant bacterial biofilm inhibition. International journal of pharmaceutics, 565, 472480.

Miao, L., Wang, C., Hou, J., Wang, P., Ao, Y., Li, Y., and $\mathrm{Xu}, \mathrm{Y} .2017$. Response of wastewater biofilm to $\mathrm{CuO}$ nanoparticle exposure in terms of extracellular polymeric substances and microbial community structure. Science of the Total Environment, 579, 588-597.

Miao, L., Wang, C., Hou, J., Wang, P., Ao, Y., Li, Y., and You, G. 2016. Aggregation and removal of copper oxide $(\mathrm{CuO})$ nanoparticles in wastewater environment and their effects on the microbial activities of wastewater biofilms. Bioresource Technology, 216, 537-544.

Misba, L., Kulshrestha, S., and Khan, A. U. 2016. Antibiofilm action of a toluidine blue O-silver nanoparticle conjugate on Streptococcus mutans: a mechanism of type I photodynamic therapy. Biofouling, 32(3), 313-328.

Mu, H., Liu, Q., Niu, H., Sun, Y., and Duan, J. 2016. Gold nanoparticles make chitosan-streptomycin conjugates effective towards Gram-negative bacterial biofilm. RSC advances, 6(11), 87148721.

N. Jones, B. Ray, K. T. Ranjit, and A. C. Manna. 2008. "Antibacterial activity of $\mathrm{ZnO}$ nano particle suspensions on a broad spectrum of microorganisms, "FEMS Microbiology Letters, vol. 279, no.1, pp.71-76.

Naha, P. C., Liu, Y., Hwang, G., Huang, Y., Gubara, S., Jonnakuti, V., and Cormode, D. P. 2019. Dextran-coated iron oxide nanoparticles as biomimetic catalysts for localized and $\mathrm{pH}$ activated biofilm disruption. ACS nano, 13(5), 4960-4971.

Naik, K., and Kowshik, M. 2014. Anti-biofilm efficacy of low temperature processed $\mathrm{AgCl}-\mathrm{TiO} 2$ nanocomposite coating. Materials Science and Engineering: C, 34, 62-68.

Neethu, S., Midhun, S. J., Radhakrishnan, E. K., and Jyothis, M. 2018. Green synthesized silver nanoparticles by marine endophytic fungus Penicillium polonicum and its antibacterial efficacy against biofilm forming, multidrugresistant Acinetobacter baumanii. Microbial pathogenesis, 116, 263-272.

Nguyen, T. K., Duong, H. T., Selvanayagam, R., Boyer, C., and Barraud, N. 2015. Iron oxide nanoparticle-mediated hyperthermia stimulates dispersal in bacterial biofilms and enhances antibiotic efficacy. Scientific reports, 5(1), 1-15.

Noreen, Z., Khalid, N. R., Abbasi, R., Javed, S., Ahmad, I., and Bokhari, H. 2019. Visible light sensitive $\mathrm{Ag} / \mathrm{TiO} 2 /$ graphene composite as a potential coating material for control of Campylobacter jejuni. Materials Science and Engineering: C, 98, 125-133.

NTaniguchi. On the Basic Concept of Nano Technology, Proc ICPE Tokyo 1974; 21:8-23.

O’Toole G, Kaplan HB, Kolter R. 2000. Biofilm formation as microbial development. Annu Rev Microbiol 54(1):49-79. https://doi.org/10.1146/annurev.micro.54.1.49

Ogawa, A., Takakura, K., Sano, K., Kanematsu, H., Yamano, T., Saishin, T., and Terada, S. 2018. Microbiome analysis of biofilms of silver nanoparticle-dispersed silane-based coated carbon steel using a next-generation sequencing technique. Antibiotics, 7(4), 91.

Ogunyemi, S. O., Abdallah, Y., Zhang, M., Fouad, H., Hong, X., Ibrahim, E., and Li, B.. 2019. Green synthesis of zinc oxide nanoparticles using different plant extracts and their antibacterial activity against Xanthomonas oryzae pv. oryzae. Artificial cells, nanomedicine, and biotechnology, 47(1), 341-352.

Ohko, Y., Y. Nagao, K. Okanoetal. 2009. "Prevention of Phormidiumtenue biofilm formation by $\mathrm{TiO} 2$ photocatalysis," Microbesand Environments, vol.24, no.3, pp. 241-245.

Ouyang, K., Yu, X. Y., Zhu, Y., Gao, C., Huang, Q., and Cai, P. 2017. Effects of humic acid on the interactions between zinc oxide nanoparticles and bacterial biofilms. Environmental Pollution, 231, 1104-1111.

P.S.Murthy,V.Venugopalan,D.A.Das,S.Dhara,R.Pandi yan, and A. Tyagi.2011. "Antibiofilm activity of nano sized CuO," in Proceedings of the International Conference on Nanoscience, Engineering and Technology(ICONSET'11), pp.580-583,IEEE.

Pant, J., Goudie, M. J., Hopkins, S. P., Brisbois, E. J., and Handa, H. 2017. Tunable nitric oxide release from S-nitroso-N-acetylpenicillamine via catalytic copper nanoparticles for biomedical applications. ACS applied materials and interfaces, 9(18), 15254-15264.

Patel, K. K., Surekha, D. B., Tripathi, M., Anjum, M. M., Muthu, M. S., Tilak, R., and Singh, S.. 2019. Antibiofilm potential of silver sulfadiazine-loaded nanoparticle formulations: a study on the effect of DNase-I on microbial biofilm and wound healing activity. Molecular pharmaceutics, 16(9), 39163925.

Patil, S. S., Patil, R. H., Kale, S. B., Tamboli, M. S., 
Ambekar, J. D., Gade, W. N. and Kale, B. B. 2014. Nanostructured microspheres of silver@ zinc oxide: an excellent impeder of bacterial growth and biofilm. Journal of nanoparticle research, 16(11), 2717.

Pham, D. T. N., Khan, F., Phan, T. T. V., Park, S. K., Manivasagan, P., Oh, J., and Kim, Y. M. 2019. Biofilm inhibition, modulation of virulence and motility properties by $\mathrm{FeOOH}$ nanoparticle in Pseudomonas aeruginosa. Brazilian Journal of Microbiology, 50(3), 791-805.

Pihl, M., Bruzell, E., and Andersson, M. 2017. Bacterial biofilm elimination using gold nanorod localised surface plasmon resonance generated heat. Materials Science and Engineering: $C$, 80, 54-58.

Porter, G. C., Tompkins, G. R., Schwass, D. R., Li, K. C., Waddell, J. N., and Meledandri, C. J. 2020. Anti-biofilm activity of silver nanoparticlecontaining glass ionomer cements. Dental Materials.

Pugazhendhi, A., Kumar, S. S., Manikandan, M., and Saravanan, M. 2018. Photocatalytic properties and antimicrobial efficacy of $\mathrm{Fe}$ doped $\mathrm{CuO}$ nanoparticles against the pathogenic bacteria and fungi. Microbial pathogenesis, 122, 84-89.

Punniyakotti, P., Panneerselvam, P., Perumal, D., Aruliah, R., and Angaiah, S. 2020. Anti-bacterial and anti-biofilm properties of green synthesized copper nanoparticles from Cardiospermum halicacabum leaf extract. Bioprocess and Biosystems Engineering, 1-9.

Q.Yu, J. Li, Y. Zhang, Y. Wang, L.Liu, and M. Li, 2016 "Inhibition of gold nanoparticles (AuNPs) on pathogenic biofilm formation and invasion to host cells," Scientific Reports, vol. 6, Article ID 26667.

Rajkumari, J., Busi, S., Vasu, A. C., and Reddy, P. 2017. Facile green synthesis of baicalein fabricated gold nanoparticles and their antibiofilm activity against Pseudomonas aeruginosa PAO1. Microbial pathogenesis, 107, 261-269.

Rajkumari, J., Magdalane, C. M., Siddhardha, B., Madhavan, J., Ramalingam, G., Al-Dhabi, N. A., and Kaviyarasu, K. 2019. Synthesis of titanium oxide nanoparticles using Aloe barbadensis mill and evaluation of its antibiofilm potential against Pseudomonas aeruginosa PAO1. Journal of Photochemistry and Photobiology B: Biology, 201, 111667.

Rajkumari, J., Meena, H., Gangatharan, M., and Busi, S. 2017. Green synthesis of anisotropic gold nanoparticles using hordenine and their antibiofilm efficacy against Pseudomonas aeruginosa. IET nanobiotechnology, 11(8), 987-994.

Ramalingam, V., Dhinesh, P., Sundaramahalingam, S., and Rajaram, R. 2019. Green fabrication of iron oxide nanoparticles using grey mangrove Avicennia marina for antibiofilm activity and in vitro toxicity. Surfaces and Interfaces, 15, 70-77.

Ramasamy, M., and Lee, J. 2016. Recent nanotechnology approaches for prevention and treatment of biofilm-associated infections on medical devices. BioMed Research International,2016

Ramasamy, M., Lee, J. H., and Lee, J. 2017. Direct one-pot synthesis of cinnamaldehyde immobilized on gold nanoparticles and their antibiofilm properties. Colloids and Surfaces B: Biointerfaces, 160, 639-648.

Ramezani Ali Akbari, K., and Abdi Ali, A. 2017. Study of antimicrobial effects of several antibiotics and iron oxide nanoparticles on biofilm producing Pseudomonas aeruginosa. Nanomedicine Journal, 4(1), 37-43.

Ranmadugala, D., Ebrahiminezhad, A., Manley-Harris, M., Ghasemi, Y., and Berenjian, A. 2018. Magnetic immobilization of bacteria using iron oxide nanoparticles. Biotechnology letters, 40(2), 237-248.

Rasool, U., Sah, S. K., and Hemalatha, S. 2019. Effect of biosynthesized copper nanoparticles (CuNPs) on the growth and biofilm formation of fluconazole-resistant Candida albicans. Journal of Microbiology, Biotechnology and Food Sciences, 9(1).

Salam, F. D., Vinita, M. N., Puja, P., Prakash, S., Yuvakkumar, R., and Kumar, P. 2020. Antibacterial and anti-biofilm efficacies of bioinspired gold nanoparticles. Materials Letters, 261, 126998.

Saleh, S., Taha, M. O., Haddadin, R. N., Marzooqa, D., and Hodali, H. 2011. Preparation of silver-and zinc-doped mullite-based ceramics showing antibacterial biofilm properties. Molecules, 16(4), 2862-2870.

Salem, W., Leitner, D. R., Zingl, F. G., Schratter, G., Prassl, R., Goessler, W. and Schild, S. 2015. Antibacterial activity of silver and zinc nanoparticles against Vibrio cholerae and enterotoxic Escherichia coli. International Journal of Medical Microbiology, 305(1), 85-95.

Salman, J. A., Mohammed, F., Raghad, A. A., and Inas, A. S. 2015. Antibiofilm effect of iron oxide nanoparticles synthesized by Lactobacillus fermentum on catheter. World Journal of Pharmaceutical Research, 4(8).

Sambalova, O., Thorwarth, K., Heeb, N. V., Bleiner, D., Zhang, Y., Borgschulte, A., and Kroll, A. 2018. Carboxylate functional groups mediate interaction with silver nanoparticles in biofilm matrix. ACS omega, 3(1), 724-733.

Saravanakumar, K., Jeevithan, E., Hu, X., Chelliah, R., 
Oh, D. H., and Wang, M. H. 2020. Enhanced antilung carcinoma and anti-biofilm activity of fungal molecules mediated biogenic zinc oxide nanoparticles conjugated with $\beta$-D-glucan from barley. Journal of Photochemistry and Photobiology B: Biology, 203, 111728.

Sathyanarayanan, M. B., Balachandranath, R., Genji Srinivasulu, Y., Kannaiyan, S. K., and Subbiahdoss, G. 2013. The effect of gold and ironoxide nanoparticles on biofilm-forming pathogens. International Scholarly Research Notices, 2013.

Schleyer TL. Nanodentistry. Fact or Fiction? J Am Dent Assoc 2000; 131:1567-1568.

Schug, H., Isaacson, C. W., Sigg, L., Ammann, A. A., and Schirmer, K. 2014. Effect of $\mathrm{TiO} 2$ nanoparticles and UV radiation on extracellular enzyme activity of intact heterotrophic biofilms. Environmental science and technology, 48(19), 11620-11628.

Secinti, K. D., Özalp, H., Attar, A., and Sargon, M. F. 2011. Nanoparticle silver ion coatings inhibit biofilm formation on titanium implants. Journal of Clinical Neuroscience, 18(3), 391-395.

Seil, J. T., and Webster, T. J. 2011. Reduced Staphylococcus aureus proliferation and biofilm formation on zinc oxide nanoparticle PVC composite surfaces. Acta Biomaterialia, 7(6), 2579-2584.

Shakerimoghaddam, A., Razavi, D., Rahvar, F., Khurshid, M., Moghadam Ostadkelayeh, S., Esmaeili, S. A., and Eshraghi, M. 2020. Evaluate the effect of zinc oxide and silver nanoparticles (ZnO-Ag NPs) on biofilm and icaA gene expression in methicillin-resistant Staphylococcus aureus (MRSA) isolated from burn wound infection. Journal of Burn Care and Research.

Shakibaie, M., Alipour-Esmaeili-Anari, F., AdeliSardou, M., Ameri, A., Doostmohammadi, M., Forootanfar, H., and Ameri, A. 2019. Antibacterial and anti-biofilm effects of microwave-assisted biologically synthesized zinc nanoparticles. Nanomedicine Journal, 6(3), 223-231.

Shanan, Z. J., Hadi, S. M., and Shanshool, S. K. 2018. Structural analysis of chemical and green synthesis of $\mathrm{CuO}$ nanoparticles and their effect on biofilm formation. Baghdad Science Journal, 15(2), 211216.

Sheng, Z., and Liu, Y. 2011. Effects of silver nanoparticles on wastewater biofilms. Water research, 45(18), 6039-6050.

Sherwani, M. A., Tufail, S., Khan, A. A., and Owais, M. 2015. Gold nanoparticle-photosensitizer conjugate based photodynamic inactivation of biofilm producing cells: potential for treatment of C. albicans infection in BALB/c mice. PLoS One, 10(7), e0131684.
Shi, S. F., Jia, J. F., Guo, X. K., Zhao, Y. P., Chen, D. S., Guo, Y. Y., and Zhang, X. L. 2016. Reduced Staphylococcus aureus biofilm formation in the presence of chitosan-coated iron oxide nanoparticles. International journal of nanomedicine, 11, 6499.

Singh, N., Paknikar, K. M., and Rajwade, J. 2019. Gene expression is influenced due to 'nano' and 'ionic' copper in pre-formed Pseudomonas aeruginosa biofilms. Environmental research, 175, 367-375.

Singh, P., Pandit, S., Beshay, M., Mokkapati, V. R. S. S., Garnaes, J., Olsson, M. E., and Daugaard, A. E. 2018. Anti-biofilm effects of gold and silver nanoparticles synthesized by the Rhodiola rosea rhizome extracts. Artificial cells, nanomedicine, and biotechnology, 46(sup3), S886-S899.

Singh, P., Pandit, S., Garnæs, J., Tunjic, S., Mokkapati, V. R., Sultan, A., and Baun, A. 2018. Green synthesis of gold and silver nanoparticles from Cannabis sativa (industrial hemp) and their capacity for biofilm inhibition. International journal of nanomedicine, 13, 3571 .

Singh, V.A., Barbul, A. 2008. Bacterial biofilms in wounds. Wound Repair and Regeneration 16, 1.

Subbiahdoss, G., Sharifi, S., Grijpma, D. W., Laurent, S., van der Mei, H. C., Mahmoudi, M., and Busscher, H. J. 2012. Magnetic targeting of surface-modified superparamagnetic iron oxide nanoparticles yields antibacterial efficacy against biofilms of gentamicin-resistant staphylococci. Acta biomaterialia, 8(6), 2047-2055.

Suresh, Y., Annapurna, S., Singh, A. K., Chetana, A., Pasha, C., and Bhikshamaiah, G. 2016. Characterization and evaluation of anti-biofilm effect of green synthesized copper nanoparticles. Materials Today: Proceedings, 3(6), 1678-1685.

Taylor, E. N., and Webster, T. J. 2009. The use of superparamagnetic nanoparticles for prosthetic biofilm prevention. International journal of nanomedicine, 4, 145.

Taylor, E. N., Kummer, K. M., Durmus, N. G., Leuba, K., Tarquinio, K. M., and Webster, T. J. 2012. Super paramagnetic iron oxide nanoparticles (SPION) for the treatment of antibiotic- resistant biofilms. Small, 8(19), 3016-3027.

Velusamy, P., Chia-Hung, S., Shritama, A., Kumar, G. V., Jeyanthi, V., and Pandian, K. 2016. Synthesis of oleic acid coated iron oxide nanoparticles and its role in anti-biofilm activity against clinical isolates of bacterial pathogens. Journal of the Taiwan Institute of Chemical Engineers, 59, 450456.

Vijayakumar, S., Malaikozhundan, B., Saravanakumar, K., Durán-Lara, E. F., Wang, M. H., and Vaseeharan, B. 2019. Garlic clove extract assisted 
silver nanoparticle-Antibacterial, antibiofilm, antihelminthic, anti-inflammatory, anticancer and ecotoxicity assessment. Journal of Photochemistry and Photobiology B: Biology, 198, 111558.

Vijayakumar, S., Malaikozhundan, B., Shanthi, S., Vaseeharan, B., and Thajuddin, N. 2017. Control of biofilm forming clinically important bacteria by green synthesized $\mathrm{ZnO}$ nanoparticles and its ecotoxicity on Ceriodaphnia cornuta. Microbial Pathogenesis, 107, 88-97.

Vijayakumar, S., Vinoj, G., Malaikozhundan, B., Shanthi, S., and Vaseeharan, B. 2015. Plectranthus amboinicus leaf extract mediated synthesis of zinc oxide nanoparticles and its control of methicillin resistant Staphylococcus aureus biofilm and blood sucking mosquito larvae. Spectrochimica Acta Part A: Molecular and Biomolecular Spectroscopy, 137, 886-891.

W. Zhang, E. S. McLamore, N. T. Garland, J. V. C. Leon, and M. K. Banks.2013. "A simple method for quantifying biomass cell and polymer distribution in biofilms," Journal of Microbiological Methods, vol. 94, no.3, pp. 367374.

W.-Y. Chen, J.-Y. Lin, W.-J. Chen, L. Luo, E. WeiGuang Diau, andY.-C.Chen, 2010."Functional gold nanoclusters as antimicrobial agents for antibiotic-resistant bacteria," Nanomedicine, vol. 5, no.5, pp.755-764.

Wang, W., Cheng, X., Liao, J., Lin, Z., Chen, L., Liu, D., and Xia, H. 2019. Synergistic Photothermal and Photodynamic Therapy for Effective ImplantRelated Bacterial Infection Elimination and Biofilm Disruption Using Cu9S8 Nanoparticles. ACS Biomaterials Science and Engineering, 5(11), 6243-6253.

Whitesides GM, Love JC. The art of building small. Scientific American 2001; 285:33-41.

Widyńska, E., Jaworski, S., Strojny, B., and Zając, A. 2018. Influence of silver and copper nanoparticles on Staphylococcus aureus biofilm formation. Annals of Warsaw University of Life Sciences, 57(2), 193-201.

Wonoputri, V., Gunawan, C., Liu, S., Barraud, N., Yee, L. H., Lim, M., and Amal, R. 2015. Copper complex in poly (vinyl chloride) as a nitric oxidegenerating catalyst for the control of nitrifying bacterial biofilms. ACS applied materials and interfaces, 7(40), 22148-22156.

Woźniak-Budych, M. J., Przysiecka, Ł., Langer, K., Peplińska, B., Jarek, M., Wiesner, M., and Jurga, S. 2017. Green synthesis of rifampicin-loaded copper nanoparticles with enhanced antimicrobial activity. Journal of Materials Science: Materials in Medicine, 28(3), 42.

Xiao, X., Zhu, W. W., Liu, Q. Y., Yuan, H., Li, W. W., $\mathrm{Wu}$, L. J., and $\mathrm{Yu}, \mathrm{H} . \mathrm{Q}$. 2016. Impairment of biofilm formation by $\mathrm{TiO} 2$ photocatalysis through quorum quenching. Environmental science and technology, 50(21), 11895-11902.

Xu, Y., Wang, C., Hou, J., Dai, S., Wang, P., Miao, L., and You, G. 2016. Effects of $\mathrm{ZnO}$ nanoparticles and $\mathrm{Zn} 2+$ on fluvial biofilms and the related toxicity mechanisms. Science of the Total Environment, 544, 230-237.

Yang, W., Chata, G., Zhang, Y., Peng, Y., Lu, J. E., Wang, N., and Chen, S. 2019. Graphene oxidesupported zinc cobalt oxides as effective cathode catalysts for microbial fuel cell: High catalytic activity and inhibition of biofilm formation. Nano Energy, 57, 811-819.

Yu, L., Shang, F., Chen, X., Ni, J., Yu, L., Zhang, M., and Xue, T. 2018. The anti-biofilm effect of silvernanoparticle-decorated quercetin nanoparticles on a multi-drug resistant Escherichia coli strain isolated from a dairy cow with mastitis. PeerJ, 6, e5711.

Zhang, K., Melo, M. A. S., Cheng, L., Weir, M. D., Bai, Y., and Xu, H. H. 2012. Effect of quaternary ammonium and silver nanoparticle-containing adhesives on dentin bond strength and dental plaque microcosm biofilms. Dental Materials, 28(8), 842-852.

Zhang, M., Liu, X., Xie, Y., Zhang, Q., Zhang, W., Jiang, X., and Lin, J. 2020. Biological Safe Gold Nanoparticle-Modified Dental Aligner Prevents the Porphyromonas gingivalis Biofilm Formation. ACS omega.

\section{How to cite this article:}

Himasri Das. 2020. Metal Based Nanoparticles, a Novel Approach to Control Biofilm: Review. Int.J.Curr.Microbiol.App.Sci. 9(09): 3404-3421. doi: https://doi.org/10.20546/ijcmas.2020.909.423 